\title{
Clinically significant mutations in HIV-infected patients with lung adenocarcinoma
}

\author{
Jonathan Thaler ${ }^{1}$, Carlie Sigel ${ }^{2}$, Mary Beth Beasley ${ }^{1}$, Juan Wisnivesky ${ }^{1}$, Kristina Crothers ${ }^{3}$, Joshua Bauml ${ }^{4}$, \\ Kristen Hysell ${ }^{5}$, Brinda Emu ${ }^{5}$, Laetitia Borsu ${ }^{2}$ and Keith Sigel ${ }^{\star, 1}$ \\ ${ }^{1}$ Department of Medicine, Icahn School of Medicine at Mount Sinai, New York, NY 10029, USA; ${ }^{2}$ Department of Pathology, \\ Memorial Sloan Kettering Cancer Center, New York, NY 10065, USA; ${ }^{3}$ Department of Medicine, University of Washington School \\ of Medicine, Seattle, WA 98195, USA; ${ }^{4}$ Department of Medicine, University of Pennsylvania, Philadelphia, PA 19104, USA and \\ ${ }^{5}$ Department of Medicine, Yale University School of Medicine, New Haven, CT 06510, USA
}

Background: Lung cancer is a major cause of death in HIV-infected (HIV + ) persons. In this study, we compared the prevalence of tumour EGFR and KRAS mutations in a cohort of lung adenocarcinoma patients by HIV status.

\begin{abstract}
Methods: We collected data from 55 HIV + patients with lung adenocarcinoma matched to 136 uninfected comparators. We compared the prevalence of EGFR and KRAS mutations by HIV status. We then compared survival by HIV status and by cancer mutation status among HIV + subjects.
\end{abstract}

Results: Presence of KRAS and EGFR genetic alterations did not vary by HIV status (all $P>0.1$ ). There was no difference in overall survival by HIV status or by mutation status among HIV + subjects.

Conclusions: We found no major differences in the prevalence of EGFR or KRAS lung adenocarcinoma mutations by HIV statuS, suggesting that mutational testing should be conducted similarly regardless of the HIV status.

Lung cancer is the leading cause of cancer death in HIV-infected $(\mathrm{HIV}+)$ persons (Sigel et al, 2017). The incidence of lung cancer is also higher in $\mathrm{HIV}+$ compared with uninfected (HIV-) individuals (Sigel et al, 2017). Although the increased prevalence of smoking in the HIV + population contributes to an elevated risk of lung cancer, HIV itself is an independent risk factor (Ridge et al, 2013). Several explanations for this phenomenon have been proposed, including HIV-associated immunosuppression, local and systemic inflammation, and direct viral oncogenesis; however, evidence is mixed and no clear consensus has emerged (Sigel et al, 2017).

The unique lung cancer risk factors associated with HIV infection may lead to a unique oncogenic microenvironment promoting distinctive tumour genetics. With the emergence of molecularly targeted cancer therapies, testing of lung adenocarcinomas for clinically important genetic alterations, particularly EGFR (epidermal growth factor receptor) and KRAS (Kirsten Rat Sarcoma), has become more common. EGFR-positive $(E G F R+)$ tumours are found most commonly in never-smokers and Asians, and are associated with good prognosis because of susceptibility to tyrosine kinase inhibitors; common pathogenic mutation loci include exons 19, 20, and 21 (Bauml et al, 2013; Ridge et al, 2013; Khalil and Altiok, 2015). KRAS is the most frequently mutated gene in adenocarcinoma of the lung, and KRAS-positive (KRAS +) tumours are associated with smoking exposure; exon 2 (codons 12 and 13) is the most common pathogenic mutation locus. The prognostic import of KRAS+ is controversial and there are no FDA-approved targeted therapies for this mutation (Ridge et al, 2013; Crequit et al, 2016). Testing for ALK (Anaplastic Lymphoma Kinase) rearrangements has also become common because of targeted therapy that improves outcomes for tumours with these alterations (Ridge et al, 2013). There are limited data, however, regarding the prevalence of these mutations in HIV + persons; although recent reports suggest that rates may be similar to those in uninfected persons, there have been no direct comparisons to controls (Moltó et al, 2015; Crequit et al, 2016).

*Correspondence: Dr K Sigel; E-mail: keith.sigel@mssm.edu

Received 8 May 2017; revised 6 August 2017; accepted 30 August 2017; published online 21 September 2017

(C) 2017 Cancer Research UK. All rights reserved 0007-0920/17 
A better understanding of these mutational profiles could lead to insights into the pathophysiologic pathways of lung cancer development in $\mathrm{HIV}+$ persons and could inform treatment and prognostic assessment for these patients. This study aimed to determine the prevalence of EGFR and KRAS mutations and $A L K$ rearrangements in lung adenocarcinomas in $\mathrm{HIV}+$ patients and to examine factors associated with the presence of these mutations as well as their effect on prognosis.

\section{MATERIALS AND METHODS}

Study cohort. We identified all HIV + NSCLC cases at Mount Sinai Hospital, Yale University Medical Center, University of Pennsylvania, and Memorial Sloan-Kettering Cancer Center (MSKCC) with adenocarcinoma histologic subtype and available cancer mutation data from 2006 to $2016(n=55)$. We excluded patients with non-adenocarcinoma NSCLC as EGFR and KRAS mutations are rare and of unclear clinical significance in these subtypes (Ettinger et al, 2015). Data were collected on demographics; cancer stage, first course of cancer treatment, and final outcome; smoking status; and, for HIV + patients, HIV RNA levels and CD4 counts at cancer diagnosis. We assembled a comparison group of HIV - NSCLC patients from a MSKCC lung cancer mutation database $(n=5471)$ and matched the $55 \mathrm{HIV}+$ NSCLC patients to one or two (when available) HIV - controls $(n=136)$ by age, sex, race, and smoking status (current, former, or never).

Our primary outcome of interest was lung cancer mutation status. We collected data on EGFR and KRAS mutations, as well as $A L K$ rearrangement status, which was available for only a subset of the HIV + cohort (45\%) and for none of the comparators. Specific mutations of interest included EGFR exons 19, 20, and 21 and KRAS exon 2 (including codons 12 and 13). Patients with any EGFR or KRAS mutations were classified as EGFR + or KRAS +, respectively.

Statistical analysis. We compared clinical and demographic characteristics by HIV status using $\chi^{2}$ and Fisher's exact test (where appropriate) for categorical variables and the $t$-test for continuous variables. Frequencies of EGFR and KRAS mutations were determined and compared for the HIV + and uninfected groups. Among HIV + patients, we identified clinical and demographic variables associated with EGFR and KRAS mutations. We also used Kaplan-Meier methods to compare overall survival (OS) by HIV status, and among $\mathrm{HIV}+$ cases compared OS for those with and without EGFR and KRAS mutations (no subjects were positive for mutations in both genes). On the basis of the prevalence of lung cancer mutations expected in the general population, we estimated that the study had an $80 \%$ power to detect at least a $20 \%$ difference in the proportion of lung cancer mutations by HIV status. All analyses were performed using STATA 13 (Stata Corp, College Station, TX, USA).

\section{RESULTS}

We identified $55 \mathrm{HIV}+$ subjects with lung adenocarcinomas and available mutation information at the participating institutions, and 136 uninfected, matched comparators. The matched cohort was largely male (Table 1), current or former smokers, and of black race. There were no differences in age at cancer diagnosis by HIV status, but year of cancer diagnosis was later for HIV + persons than for uninfected ones $(P<0.01)$. Initial course of lung cancer treatment was similar for HIV + and uninfected persons $(P \geqslant 0.05$
Table 1. Characteristics of non-small cell lung cancer patients by HIV status

\begin{tabular}{|c|c|c|c|}
\hline & $\begin{array}{c}\text { HIV infected, } \\
\mathbf{N}=\mathbf{5 5}\end{array}$ & $\begin{array}{c}\text { Uninfected, } \\
N=136\end{array}$ & $P$-value \\
\hline Age, years (median, IQR) & 57,14 & 57,11 & 0.6 \\
\hline Female, $N(\%)$ & $18(33)$ & $38(28)$ & 0.5 \\
\hline $\begin{array}{l}\text { Race/ethnicity, N (\%) } \\
\text { Black } \\
\text { White } \\
\text { Other } \\
\text { Unknown }\end{array}$ & $\begin{array}{c}28(51) \\
15(27) \\
10(18) \\
2(4)\end{array}$ & $\begin{array}{c}58(43) \\
45(33) \\
30(22) \\
3(2)\end{array}$ & 0.6 \\
\hline $\begin{array}{l}\text { Smoking status, } N(\%) \\
\text { Never smoker } \\
\text { Current/former smoker } \\
\text { Unknown }\end{array}$ & $\begin{array}{c}4(7) \\
49(89) \\
2(4)\end{array}$ & $\begin{array}{r}9(7) \\
123(90) \\
4(3)\end{array}$ & $>0.9$ \\
\hline $\begin{array}{l}\text { CD4 count, } N(\%) \\
\geqslant 500 \\
200-499 \\
<200 \\
\text { Unknown }\end{array}$ & $\begin{aligned} 23 & (42) \\
16 & (29) \\
5 & (9) \\
11 & (20)\end{aligned}$ & & \\
\hline $\begin{array}{l}\text { HIV RNA, N (\%) } \\
\text { Undetectable } \\
\text { Detectable } \\
\text { Unknown }\end{array}$ & $\begin{array}{l}16(29) \\
18(33) \\
21(38)\end{array}$ & & \\
\hline $\begin{array}{l}\text { ARV status, } N(\%) \\
\text { On ARV } \\
\text { Off ARV } \\
\text { Unknown }\end{array}$ & $\begin{array}{c}48(87) \\
5(9) \\
2(4)\end{array}$ & & \\
\hline $\begin{array}{l}\text { Year of cancer diagnosis, } \\
\text { N (\%) } \\
\text { 2006-2008 } \\
2009-2011 \\
\text { 2012-2014 } \\
\text { 2015-Present }\end{array}$ & $\begin{aligned} & 4(7) \\
9 & (16) \\
29 & (53) \\
13 & (24)\end{aligned}$ & $\begin{array}{c}35(26) \\
81(60) \\
20(14) \\
0(0)\end{array}$ & $<0.01$ \\
\hline $\begin{array}{l}\text { Tumour stage, } N(\%) \\
\text { I } \\
\text { II } \\
\text { III } \\
\text { IV } \\
\text { Unknown }\end{array}$ & $\begin{aligned} 11 & (20) \\
3 & (5) \\
9 & (16) \\
27 & (49) \\
5 & (10)\end{aligned}$ & $\begin{array}{c}11(8) \\
1(1) \\
19(14) \\
75(55) \\
30(22)\end{array}$ & 0.01 \\
\hline Chemotherapy, $N(\%)$ & $33(60)$ & $101(74)$ & 0.05 \\
\hline Radiotherapy, N (\%) & $23(42)$ & $68(50)$ & 0.3 \\
\hline Surgery, $N(\%)$ & $19(35)$ & $43(32)$ & 0.7 \\
\hline
\end{tabular}

for all comparisons). Most HIV + NSCLC cases were on antiretroviral therapy and had CD4 counts $\geqslant 500$ cells $/ \mathrm{mm}^{3}$ at the time of lung cancer diagnosis.

KRAS mutations were more common than EGFR mutations in the cohort (29\% and $10 \%$, respectively), with nearly all KRAS mutations (98\%) found in exon 2 of the gene (Supplementary Table). We found no significant differences by HIV status with respect to clinically obtained lung tumour mutations (HIV $+: 7 \%$ $E G F R+, 22 \% K R A S+$; HIV - : 11\% EGFR + , 35\% KRAS + ; both $P>0.05)$. Among HIV + subjects, EGFR + mutation status was associated with 'other' race (identified in the electronic medical record as a race other than black or white, but not unknown; Table 2; $P=0.04)$, never having smoked $(P<0.01)$, and later calendar year of cancer diagnosis $(P<0.01) ; K R A S+$ mutation status was associated with stage I cancers (as opposed to later stage; $P=0.01$ ) and lower CD4 counts $(P=0.01)$. There were no $A L K$ rearrangements seen among the $20 \mathrm{HIV}+$ subjects whose tumours were evaluated.

In unadjusted Kaplan-Meier analyses, we found no difference in OS by HIV status (Figure 1; $P=0.3$ ). Among HIV + subjects, we also found no statistically significant differences in survival when comparing KRAS+, EGFR+, and KRAS-/EGFR - cases $(P=0.4)$, although it is worth noting that all EGFR $+\mathrm{HIV}+$ cases were alive at last follow-up. 
Table 2. Characteristics of HIV-infected and uninfected groups by EGFR and KRAS mutation status

\begin{tabular}{|c|c|c|c|c|c|c|c|c|c|c|c|c|}
\hline & \multicolumn{6}{|c|}{ HIV infected } & \multicolumn{6}{|c|}{ Uninfected } \\
\hline Female, $N(\%)$ & $0(0)$ & $18(35)$ & 0.3 & $3(27)$ & $12(32)$ & $>0.9$ & $5(33)$ & $32(27)$ & 0.6 & $16(36)$ & $19(23)$ & 0.1 \\
\hline $\begin{array}{l}\text { Race/ethnicity, N (\%) } \\
\text { Black } \\
\text { White } \\
\text { Other } \\
\text { Unknown }\end{array}$ & $\begin{array}{l}1(25) \\
0(0) \\
2(50) \\
1(25)\end{array}$ & $\begin{aligned} 27(53) \\
15(29) \\
8(16) \\
1(2)\end{aligned}$ & 0.04 & $\begin{array}{l}3(27) \\
4(36) \\
3(27) \\
1(9)\end{array}$ & $\begin{aligned} 22 & (58) \\
8 & (21) \\
7 & (18) \\
1 & (3)\end{aligned}$ & 0.2 & $\begin{array}{l}4(27) \\
3(20) \\
8(53) \\
0(0)\end{array}$ & $\begin{array}{c}52(44) \\
42(35) \\
22(19) \\
3(2)\end{array}$ & 0.02 & $\begin{aligned} 23 & (51) \\
17 & (38) \\
5 & (11) \\
0 & (0)\end{aligned}$ & $\begin{array}{c}33(39) \\
27(32) \\
21(25) \\
3(4)\end{array}$ & 0.1 \\
\hline $\begin{array}{l}\text { Smoking status, } N(\%) \\
\text { Never smoker } \\
\text { Current/former Smoker } \\
\text { Unknown }\end{array}$ & $\begin{array}{l}4(100) \\
0(0) \\
0(0)\end{array}$ & $\begin{array}{c}0(0) \\
49(96) \\
2(4)\end{array}$ & $<0.01$ & $\begin{array}{c}0(0) \\
11(100) \\
0(0)\end{array}$ & $\begin{array}{c}4(11) \\
32(84) \\
2(5)\end{array}$ & 0.7 & $\begin{array}{c}4(27) \\
10(67) \\
1(6)\end{array}$ & $\begin{array}{c}5(4) \\
112(94) \\
2(2)\end{array}$ & $<0.01$ & $\begin{aligned} & 1(2) \\
& 43(96) \\
& 1\end{aligned}$ & $\begin{array}{c}6(7) \\
75(89) \\
3(4)\end{array}$ & 0.4 \\
\hline $\begin{array}{l}\text { CD4 count, } N(\%) \\
\geqslant 500 \\
200-499 \\
<200 \\
\text { Unknown }\end{array}$ & $\begin{array}{l}2(50) \\
0(0) \\
0(0) \\
2(50)\end{array}$ & $\begin{array}{r}21(41) \\
16(31) \\
5(10) \\
9(18)\end{array}$ & 0.4 & $\begin{array}{l}1(9) \\
8(73) \\
0(0) \\
2(18)\end{array}$ & $\begin{array}{r}18(47) \\
8(21) \\
4(11) \\
8(21)\end{array}$ & 0.01 & & & & & & \\
\hline $\begin{array}{l}\text { HIV RNA, N (\%) } \\
\text { Undetectable } \\
\text { Detectable } \\
\text { Unknown }\end{array}$ & $\begin{array}{l}1(25) \\
1(25) \\
2(50)\end{array}$ & $\begin{array}{l}15(29) \\
17(33) \\
19(37)\end{array}$ & $>0.9$ & $\begin{array}{l}4(36) \\
3(27) \\
4(36)\end{array}$ & $\begin{array}{l}12(32) \\
14(37) \\
12(32)\end{array}$ & 0.8 & & & & & & \\
\hline $\begin{array}{l}\text { ARV status, } N(\%) \\
\text { On ARV } \\
\text { Off ARV } \\
\text { Unknown }\end{array}$ & $\begin{array}{l}3(75) \\
1(25) \\
0(0)\end{array}$ & $\begin{array}{l}45(88) \\
4(8) \\
2(4)\end{array}$ & 0.4 & $\begin{array}{l}10(91) \\
1(9) \\
0(0)\end{array}$ & $\begin{array}{c}33(87) \\
3(8) \\
2(5)\end{array}$ & $>0.9$ & & & & & & \\
\hline $\begin{array}{l}\text { Year of cancer diagnosis, } \\
\text { N (\%) } \\
\text { 2006-2008 } \\
\text { 2009-2011 } \\
\text { 2012-2014 } \\
\text { 2015-Present }\end{array}$ & $\begin{array}{l}0(0) \\
0(0) \\
0(0) \\
4(100)\end{array}$ & $\begin{aligned} 4 & (8) \\
9 & (18) \\
29 & (57) \\
9 & (18)\end{aligned}$ & $<0.01$ & $\begin{array}{l}1(9) \\
2(18) \\
7(64) \\
1(9)\end{array}$ & $\begin{aligned} 3 & (8) \\
5 & (13) \\
19 & (50) \\
11 & (29)\end{aligned}$ & 0.6 & $\begin{aligned} 5 & (33) \\
10 & (67) \\
0 & (0) \\
0 & (0)\end{aligned}$ & $\begin{array}{l}30(25) \\
70(59) \\
19(16) \\
0(0)\end{array}$ & 0.2 & $\begin{array}{l}14(31) \\
25(56) \\
6(13) \\
0(0)\end{array}$ & $\begin{array}{l}17(20) \\
53(63) \\
14(17) \\
0(0)\end{array}$ & 0.4 \\
\hline Radiotherapy, N (\%) & $0(0)$ & $23(45)$ & 0.1 & $3(27)$ & $17(45)$ & 0.5 & $9(60)$ & $58(49)$ & 0.4 & $23(51)$ & $42(50)$ & 0.9 \\
\hline Surgery, $N(\%)$ & $0(0)$ & $19(37)$ & 0.3 & 7 (64) & $11(29)$ & 0.04 & $1(7)$ & 41 (34) & 0.03 & $15(33)$ & 27 (32) & 0.9 \\
\hline
\end{tabular}

\section{DISCUSSION}

HIV infection has been associated with unique effects on the lung microenvironment that may affect tumour development and tumour genetic alterations. In our multicentre cohort of persons with lung adenocarcinoma, however, we found no difference in the prevalence EGFR or KRAS mutations by HIV status. These results suggest that mutational testing of lung adenocarcinomas should not vary based on HIV status.

HIV-specific factors, including abnormal immune activation and immunosuppression, have been independently associated with lung cancer and may contribute to a unique environment potentially modulating the genetic alterations that drive carcinogenesis (Sigel et al, 2016, 2017). This was initially supported by a report of increased prevalence of microsatellite instability in the DNA of lung tumours in HIV + patients (Wistuba et al, 1998). Furthermore, previous data have suggested potential links between KRAS and EGFR and HIV infection. The prevalence of EGFR tumour genetic alterations has been found to be elevated in both ophthalmologic and anal malignancies in HIV + cohorts, and EGFR polymorphisms have been tied to HIV disease progression (Chinn et al, 2010;
Verma, 2015). Although KRAS has not been closely examined in the setting of lung tumour pathophysiology in HIV + patients, a high incidence of KRAS mutations has been noted in HIV-related lymphomas and HIV-associated activation of the RAS pathway has been implicated in the development of Kaposi Sarcoma (Knowles, 1997; Knowles, 2003; Toschi et al, 2006).

Our study is the first to compare lung tumour genetics from a $\mathrm{HIV}+$ cohort to those from a matched uninfected comparison group. Rates of EGFR and KRAS mutations in NSCLC in HIV + patients were recently estimated at $3.3 \%$ and $29 \%$, respectively, in a French cohort of $63 \mathrm{HIV}+$ lung cancer patients, and a 2015 Japanese study found an EGFR mutation rate of 36\% among $\mathrm{HIV}+$ patients, consistent with the rate seen in lung tumours in the Japanese general population (Molto et al, 2015; Crequit et al, 2016). Lack of a control group in both studies, however, prevented direct comparison with uninfected patients. In our study that included a matched comparison group, we found no significant differences between HIV + and uninfected groups with respect to EGFR and KRAS mutations.

Unlike some ART-era population-based studies of lung cancer outcomes in HIV + persons (Shiels et al, 2010; Sigel et al, 2013), we found no differences in OS for NSCLC cases by HIV status. Although 


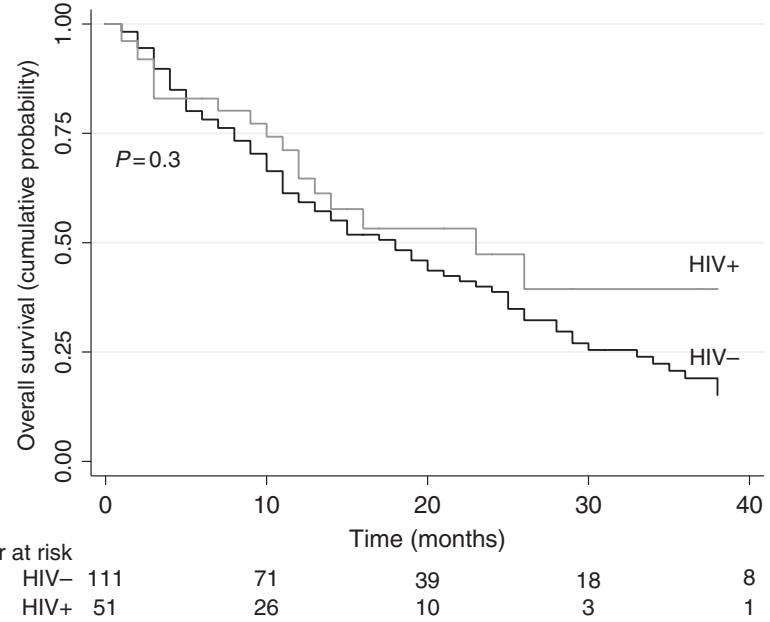

Figure 1. Overall survival for lung adenocarcinomas by HIV status.

large population-based studies have found evidence of lung cancer treatment disparities in the setting of HIV infection (Suneja, 2013), we found similar rates of surgical resection and radiotherapy by HIV status. Our HIV + cancer cases were relatively recently collected, which may explain the similarities in OS and lack of treatment disparities due to improved HIV disease management and increased comfort with managing lung cancer in this population by oncologists and surgeons, particularly in academic centres.

This study's strengths included its multicentre nature and large pool of comparator cases that yielded a matched control group. Our study was limited by a retrospective approach and relatively small sample size limiting power for comparisons. Because all cases were identified at large, academic medical centres in the northeastern United States, further study is required to determine whether these results are universally applicable to HIV + lung cancer patients.

\section{CONCLUSION}

We found no significant differences in the prevalence of EGFR and KRAS lung adenocarcinoma mutations by HIV status. Prospective studies implementing more extensive genetic alteration panels may elucidate the potential differences in lung cancer pathogenesis associated with HIV infection.

\section{ACKNOWLEDGEMENTS}

The MSKCC Sequenom Facility was supported by the Anbinder Fund. This work was supported in part by the Cancer Center Support Grant of the National Institutes of Health/National Cancer Institute under award numbers P30CA008748, R01CA210806, K07CA180782, and R01CA173754. This study was approved by the Icahn School of Medicine Institutional Review Board. The content is solely the responsibility of the authors and does not necessarily represent the official views of the National Institutes of Health.

\section{REFERENCES}

Bauml J, Mick R, Zhang Y, Watt CD, Vachani A, Aggarwal C, Evans T, Langer C (2013) Frequency of EGFR and KRAS mutations in patients with non small cell lung cancer by racial background: do disparities exist? Lung Cancer 81(3): 347-353.

Chinn LW, Tang M, Kessing BD, Lautenberger JA, Troyer JL, Malasky MJ, McIntosh C, Kirk GD, Wolinsky SM, Buchbinder SP, Gomperts ED, Goedert JJ, O'Brien SJ (2010) Genetic associations of variants in genes encoding HIV-dependency factors required for HIV-1 infection. J Infect Dis 202(12): 1836-1845.

Crequit P, Ruppert AM, Rozensztajn N, Gounant V, Vieira T, Poulot V, Antoine M, Chouaid C, Wislez M, Cadranel J, Lavole A (2016) EGFR and KRAS mutation status in non-small-cell lung cancer occurring in HIV-infected patients. Lung Cancer 96: 74-77.

Ettinger DS, Wood DE, Akerley W, Bazhenova LA, Borghaei H, Camidge DR, Cheney RT, Chirieac LR, D'Amico TA, Demmy TL, Dilling TJ, Dobelbower MC, Govindan R, Grannis Jr FW, Horn L, Jahan TM, Komaki R, Krug LM, Lackner RP, Lanuti M, Lilenbaum R, Lin J, Loo Jr BW, Martins R, Otterson GA, Patel JD, Pisters KM, Reckamp K, Riely GJ, Rohren E, Schild SE, Shapiro TA, Swanson SJ, Tauer K, Yang SC, Gregory K, Hughes M (2015) Non-small cell lung cancer, version 6.2015. J Natl Compr Cancer Netw 13(5): 515-524.

Khalil FK, Altiok S (2015) Advances in EGFR as a predictive marker in lung adenocarcinoma. Cancer Control 22(2): 193-199.

Knowles DM (1997) Molecular pathology of acquired immunodeficiency syndrome-related non-Hodgkin's lymphoma. Semin Diagn Pathol 14(1): 67-82.

Knowles DM (2003) Etiology and pathogenesis of AIDS-related nonHodgkin's lymphoma. Hematol Oncol Clin North Am 17(3): 785-820.

Moltó J, Moran T, Sirera G, Clotet B (2015) Lung cancer in HIV-infected patients in the combination antiretroviral treatment era. Transl Lung Cancer Res 4(6): 678-688.

Ridge CA, McErlean AM, Ginsberg MS (2013) Epidemiology of lung cancer. Semin Intervent Radiol 30(2): 93-98.

Shiels MS, Cole SR, Mehta SH, Kirk GD (2010) Lung cancer incidence and mortality among HIV-infected and HIV-uninfected injection drug users. J Acquir Immune Defic Syndr 55(4): 510-515.

Sigel K, Crothers K, Dubrow R, Krauskopf K, Jao J, Sigel C, Moskowitz A, Wisnivesky J (2013) Prognosis in HIV-infected patients with non-small cell lung cancer. Br J Cancer 109(7): 1974-1980.

Sigel K, Makinson A, Thaler J (2017) Lung cancer in persons with HIV. Curr Opin HIV AIDS 12(1): 31-38.

Sigel K, Pitts R, Crothers K (2016) Lung malignancies in HIV infection. Semin Respir Crit Care Med 37(2): 267-276.

Sigel K, Wisnivesky J, Crothers K, Gordon K, Brown ST, Rimland D, Rodriguez-Barradas MC, Gibert C, Goetz MB, Bedimo R, Park LS, Dubrow R (2017) Immunological and infectious risk factors for lung cancer in US veterans with HIV: a longitudinal cohort study. Lancet HIV 4(2): e67-e73.

Suneja G (2013) Disparities in the treatment and outcomes of lung cancer among HIV-infected individuals. AIDS 27(3): 459-468.

Toschi E, Bacigalupo I, Strippoli R, Chiozzini C, Cereseto A, Falchi M, Nappi F, Sgadari C, Barillari G, Mainiero F, Ensoli B (2006) HIV-1 Tat regulates endothelial cell cycle progression via activation of the Ras/ERK MAPK signaling pathway. Mol Biol Cell 17(4): 1985-1994.

Verma M (2015) Epigenetic regulation of HIV, AIDS, and AIDS-related malignancies. Methods Mol Biol 1238: 381-403.

Wistuba II, Behrens C, Milchgrub S, Virmani AK, Jagirdar J, Thomas B, Ioachim HL, Litzky LA, Brambilla EM, Minna JD, Gazdar AF (1998) Comparison of molecular changes in lung cancers in HIV-positive and HIV-indeterminate subjects. JAMA 279(19): 1554-1559.

This work is published under the standard license to publish agreement. After 12 months the work will become freely available and the license terms will switch to a Creative Commons AttributionNonCommercial-Share Alike 4.0 Unported License.

The authors declare no conflict of interest.

Supplementary Information accompanies this paper on British Journal of Cancer website (http://www.nature.com/bjc) 